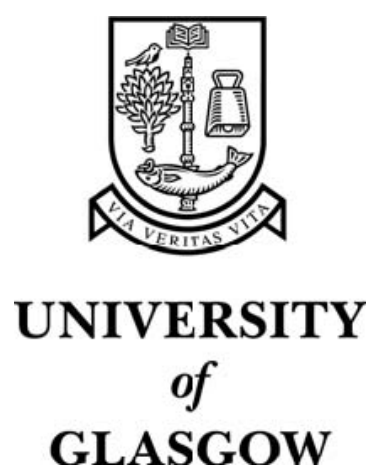

Danbolt, J. (2004) Target company cross-border effects in acquisitions into the UK. European Financial Management 10(1):pp. 83-108.

http://eprints.gla.ac.uk/3691/ 


\title{
Target Company Cross-Border Effects in Acquisitions into the UK
}

\author{
Jo Danbolt \\ J.Danbolt@accfin.gla.ac.uk \\ University of Glasgow
}

\begin{abstract}
We analyze the abnormal returns to target shareholders in cross-border and domestic acquisitions of UK companies. The cross-border effect during the bid month is small (0.84 percentage points), although cross-border targets gain significantly more than domestic targets during the months surrounding the bid. We find no evidence for the level of abnormal returns in cross-border acquisitions to be associated with market access or exchange rate effects, and only limited support for an international diversification effect. However, the cross-border effect appears to be associated with significant payment effects, and there is no significant residual cross-border effect once various bid characteristics are controlled for.
\end{abstract}

JEL Classification: G34, G14, G15

Keywords: $\quad$ Mergers and acquisitions; shareholder returns; cross-border; differential wealth effects

\section{Address for Correspondence:}

Jo Danbolt, University of Glasgow, Department of Accounting and Finance, 65-73 Southpark Avenue, Glasgow G12 8LE, United Kingdom. Tel: +44 (0)141 330 6289; Fax: +44 (0)141 330 4442; E-mail: j.danbolt@accfin.gla.ac.uk

\section{Acknowledgements:}

I would like to express my gratitude to José Manuel Campa, Diderik Danbolt, Paul Draper, Robert Durand, Carlos Garcia-Pont, Neil Garrod, Alan Gregory, Marco Guidi, Ian Hirst, Alan Hodgson, John Holland, Pinam Lampaphayom, Robin Limmack, Bill Rees, Rob Watson, Pauline Weetman, Clas Whilborg and an anonymous referee, as well as the participants the European Financial Management Association/IESE Conference on “European M\&As, Corporate Restructuring and Consolidation Issues” in Barcelona (March 2002) for helpful comments on earlier versions of this paper. I would also like to thank Gavin Wilkins for research assistance and Kirsty Husband for library assistance. The responsibility for any remaining errors or omissions rests fully with the author.

\section{Executive Summary}


During the late 1980s and early 1990s, cross-border acquisitions into the UK rose to record levels. In this paper we explore various hypotheses as to why we might expect the levels of target company abnormal returns to differ systematically between domestic and cross-border acquisitions, and test these hypotheses on a sample of 514 domestic and 116 cross-border acquisitions into the UK over the 1986-1991 period.

During the month of the bid announcement, UK targets gain significantly in both domestic and cross-border acquisitions, with abnormal returns (using the size deciles model) of $18.76 \%$ and $19.60 \%$ in domestic and cross-border acquisitions, respectively. The additional gain to targets in cross-border acquisitions - the cross-border effect - is small (0.84 percentage points), and is not statistically significant. However, during the months prior to and following the bid, target abnormal returns are significantly higher in bids by foreign acquirors, and significant cross-border effects are observed if longer time periods around the bid announcement are analyzed. Indeed, over the four-month period from $\mathrm{t}-2$ to $\mathrm{t}+1$ (where $\mathrm{t}$ refers to the month of the bid announcement), shareholders in UK companies acquired by overseas companies on average gain 10.07 percentage points more than do targets in domestic UK acquisitions, at $30.71 \%$ compared to $20.64 \%$.

We test three hypotheses as to why a target company cross-border effect may be present: the international diversification hypothesis, the market access hypothesis, and the exchange rate hypothesis. The international diversification hypothesis is tested by analyzing the extent to which abnormal returns vary with the location of the overseas bidder. We find some variations in the level of abnormal returns in cross-border acquisitions depending on where the bidding company is based, with targets gaining somewhat more from acquisitions by bidders located outside Europe or the US than in other cross-border acquisitions. However, this result is only significant for one of three event windows, and is not robust. There is thus only limited support for the international diversification hypothesis.

It has been argued that market access is a key motive for foreign direct investment (Pringle (1991)). It can therefore be hypothesized that bidders without operations in either the UK or in other EU member states prior to the acquisition will be prepared to pay higher premia than other cross-border bidders. However, we find that whether or not the bidder had prior UK operations does not have a significant impact on the level of abnormal returns to UK targets. There is thus no support for the UK market access hypothesis. We further find UK targets to gain somewhat more where the overseas bidder already had operations within the EU, contrary to the predictions of the EU market access hypothesis, which we therefore reject. There is thus no evidence of the level of target company returns in crossborder acquisitions being positively related to acquiring companies seeking either UK or EU market access.

The last hypothesis to be tested relates to the impact of exchange rates. Froot and Stein (1991) suggest that target shareholders may gain more when the currency of the target country is relatively weak compared to the currency of the acquiring company's home country. Our data suggests, however, that UK targets gained insignificantly more, rather than less, when Sterling was relatively strong. This is contrary to the predictions of the exchange rate effect hypothesis, which we therefore reject.

The level of abnormal returns in cross-border acquisitions - and hence the target company cross-border effect - thus appears not to be due to market access or exchange rate 
effects, and we find only weak support for the international diversification hypothesis.

The target company cross-border effect appears to be attributable largely to differences in the characteristics of domestic and cross-border acquisitions, and the impact of such characteristics on the level of target abnormal returns. Indeed, the level of abnormal returns is found to depend significantly on the bid characteristics, in particular the method of payment. Target shareholders gain significantly less in equity offers, and somewhat more in cash offers, in particular those with a loan note alternative (which have tax advantages compared to pure cash offers). As a significantly higher (lower) proportion of domestic than cross-border acquisitions are equity (cash, both with and without loan note alternatives) offers, this appears to account for most of the target company cross-border effect.

Other bid characteristics, including bid outcome and whether or not the bid was competitive, are also found to have a significant impact on the cross-sectional variation in the level of abnormal returns. Once bid characteristics are controlled for, the bid month cross-border effect reverses sign to -2.56 percentage points with the size deciles model, while for the longer event period from $t-2$ to $t+1$ months, the cross-border effect is reduced to an insignificant +3.26 percentage points. The cross-border effect thus appears to be largely attributable to differences in the bid characteristics of domestic and cross-border acquisitions. There is no evidence of a residual target company cross-border effect being present in the UK once the method of payment and other bid characteristics are controlled for. 


\section{Target Company Cross-Border Effects in Acquisitions into the UK}

\section{Introduction}

During the late 1980s and early 1990s, acquisitions of UK companies - and in particular the level of cross-border acquisitions into the UK - rose to new heights (Acquisitions Monthly). If capital markets and the market for corporate control are not segmented internationally, one would not expect the level of abnormal returns to target company shareholders to be systematically different in domestic and cross-border acquisitions (Fatemi and Furtado (1988), Harris and Ravenscraft (1991)). However, Kang (1993) argue that

"since the theory of FDI posits that imperfections ... give multinational firms a competitive advantage over local firms in the host country, cross-border acquisitions are likely to create more wealth than domestic acquisitions. Since targets tend to reap more of the benefits of the acquisitions, the theory suggests the wealth gains to targets of ... [foreign] firms are larger than those to targets ... [in domestic acquisitions]”. (p. 348).

In this paper we explore various hypotheses as to why we might expect target company abnormal returns to differ systematically between domestic and cross-border acquisitions, and test these hypotheses on UK data for the 1986-1991 period based on a sample of 514 domestic and 116 cross-border acquisitions into the UK. We find that during the month of the bid announcement, UK target shareholders gain significantly in both domestic and cross-border acquisitions, and the target company cross-border effect of 0.84 percentage points (with the size deciles model) is not statistically significant. However, during the months prior to and following the bid month, target abnormal returns are significantly higher for cross-border acquisitions. Target company abnormal returns in cross-border acquisitions appear to be unrelated to market access or exchange rate effects, and there is only limited support for the international diversification hypothesis. However, there is evidence to suggest that the target company cross-border effect may be related to differences in the characteristics of domestic and cross-border acquisitions. In particular, target shareholders are found to gain less from equity exchange offers (which are common in domestic acquisitions) and more from cash offers with full loan note alternatives (which are common in cross-border acquisitions) than from acquisitions with other forms of payment. Once we control for the method of payment and other bid characteristics, there is no evidence of a residual target company cross-border effect in acquisitions in the UK.

The paper is organized as follows: The factors identified in the literature as to why target shareholders may be expected to gain more in cross-border than in domestic acquisitions are discussed in section 2. This is followed by a brief discussion of prior empirical evidence on the target company cross-border effect in section 3 . In section 4 the data and methodology are explained, and section 5 presents the empirical results, which includes tests of a number of hypotheses derived from the theoretical and empirical literatures also discussed in this section. Conclusions are provided in the final section of the paper. 


\section{Target Company Cross-Border Effects - Theoretical Considerations}

Factors suggested in the literature to explain why target shareholders may gain more in cross-border than in domestic acquisitions fall into four main categories: international risk diversification; market access; exchange rate effects; and managerial factors ${ }^{1}$.

\subsection{International Risk Diversification}

While shareholders have been found to benefit from international portfolio diversification (e.g., Solnik (1974) and Davis (1991)), there is less agreement as to whether such benefits extend to corporate diversification (Sudia (1992), Markides and Ittner (1994), Hymer (1976), Jacquillat and Solnik (1978), Fatemi (1984), and Michel and Shaked (1986)). However, Hymer (1976), Hisey and Caves (1985) and Markides and Ittner (1994) argue that, under certain market inefficiencies, investors could benefit from international corporate diversification through cross-border acquisitions. For example, information asymmetries may mean that a company is better informed than its investors, and thus able to make better investment decisions than its shareholders. Markides and Ittner add that “...the multinational corporation is performing a valuable service to investors in that it allows them to diversify their portfolios indirectly". (p. 346). Thus, it can be hypothesized that corporate international diversification has the potential of being beneficial to shareholders. If international diversification is an additional source of value to overseas bidders (and they are prepared to or are forced by target shareholders to pass on part of that benefit to them), one would expect target shareholders to gain more in cross-border than in domestic acquisitions.

We test various aspects of the international diversification hypothesis in the crosssectional analysis. In addition to analyzing the differences in abnormal returns to targets in domestic and cross-border acquisitions, we also analyze whether the abnormal returns in cross-border acquisitions vary with the location of the overseas bidder. It can be hypothesized that diversification benefits will be larger in acquisitions by companies based outside Europe, than from intra-European acquisitions. However, as argued by Bodnar et al. (1997), the positive effect of international diversification may be offset by negative effects associated with industrial diversification. Consequently, we control for industry effects, and for whether the acquisition is horizontal, vertical or conglomerate, to ensure that we separate any industrial diversification effects from the potential international diversification effect.

\subsection{Market Access}

"FDI into industrial countries has always been dominated by ... [one] motive, i.e. market access.” (Pringle (1991), p. 9). International takeovers may thus be motivated by a need to operate locally in order to avoid trade barriers. This appears to have been an important issue in the cross-border takeover activity in Europe following the passing of the Single European Act in 1985, with non-EU companies actively acquiring companies within the community before the introduction of the Single European Market in 1992 (Geroski and Vlassopoulos (1990) and Vasconcellos and Kish (1998)).

If market access is valuable to foreign bidders, it may be anticipated that bidding companies without a foothold in the UK, or in any other EU member country, will be 
willing to pay higher takeover premia than bidders previously operating in these markets. In the cross-sectional analysis we test the market access hypothesis by analysing whether the level of abnormal returns in cross-border acquisitions is influenced by whether or not the acquiring company had UK or EU operations prior to the bid announcement.

\subsection{Exchange Rate Effects}

Swenson (1993) and Vasconcellos and Kish (1998) note that the level of crossborder acquisitions into the US was higher at “...times when the U.S. dollar was relatively weak” (Swenson, p. 258). Froot and Stein (1991) argue that, due to information asymmetries, external financing is costly. Thus, the higher the wealth of the entrepreneur, the lower her cost of capital. If “...foreigners hold more of their wealth in nondollardenominated form, a depreciation of the dollar increases the relative wealth position of foreigners and hence lowers their relative cost of capital. This allows them to bid more aggressively for assets”. (p. 1194). Exchange rate fluctuations might also have an impact on the level of abnormal returns to target shareholders in cross-border acquisitions. Servaes and Zenner (1990), Harris and Ravenscraft (1991), Swenson (1993) and Kang (1993) all find US target shareholders to gain more in cross-border acquisitions when the currency of the predator's home country is strong relative to the target company's currency.

Not all studies find support for the exchange rate effect. For example, Cebenoyan et al. (1992), Feils (1993), and Dewenter (1995) do not find the strength of the currency to have a significant impact on the level of abnormal returns. Morgan and Morgan (1990) argue that "when a currency fluctuates ... there are bound to be times at which it is undervalued, and these will provide bargain-hunting opportunities for overseas companies”. (p. 66). However, Cakici et al. (1991) argue that "while a devalued dollar might enable the foreign buyer to acquire an American firm at a discount, the dollar cash flows subsequent to the merger are correspondingly less valuable when converted back into the foreign currency at the current exchange rate. Thus, a low foreign exchange value of the dollar does not justify high prices for American target firms”. (p. 45). Similar arguments are put forward by Vasconcellos and Kish (1998). The theoretical issue of whether exchange rates have an impact on the level of abnormal returns to target shareholders thus remains controversial, and the empirical evidence is mixed. The impact of the exchange rate effect on the level of abnormal returns in cross-border acquisitions into the UK is tested in the cross-sectional analysis.

\subsection{Managerial Factors}

As with domestic acquisitions, cross-border acquisitions may not only be driven by shareholder wealth maximization objectives, but may also be a result of agency conflict, with bidding company management aiming to maximize their own utility. Through acquisitions, management may increase their power, status, and salary. In an analysis of domestic UK acquisitions, Firth (1991) find acquiring company management to gain from mergers and acquisitions regardless of whether their shareholders gain or lose as a result of the transactions. Bliss and Rosen (2001) obtain similar findings for bank mergers in the US. If managers are pursuing power and status through empire building, cross-border acquisitions may be more advantageous to managers than domestic transactions.

In his hubris hypothesis, Roll (1986) argues that bidding companies tend to 
overestimate the value of economic benefits of the merger. The target company bid premium may thus be the result of valuation error. If overseas companies are more difficult to value than domestic firms due to e.g., different accounting standards and valuation conventions, as well as the impact of exchange rate fluctuations on company value (Solnik (1996) and Shapiro (1999)), the size of any valuation error (and thus, the degree of any overpayment) may be larger in cross-border than in domestic acquisitions.

In an analysis of cross-border acquisitions into the UK, Danbolt (1995) finds overseas bidding companies to suffer negative abnormal returns, indicating that overseas bidders pay too high a price for their UK targets. Indeed, the post-bid performance of crossborder bidders appears to be significantly worse than the performance of domestic UK bidders (Danbolt (1996)). This suggests that any target company cross-border effect may be due to managerial overconfidence or managers of cross-border bidders pursuing the maximization of personal utility, rather than the maximization of shareholder wealth, to a greater extent than do domestic bidders.

To explicitly test for managerial factors akin to the studies of e.g., Firth (1991) and Bliss and Rozen (2001) would require detailed data on remuneration and share holdings of the managers of the overseas acquiring companies. Such data is not available for the current research project. Rather, we treat managerial factors as a residual category. If a target company cross-border effect is found to be present - after controlling for international risk diversification, market access and exchange rate effects (as well as for various bid characteristics, discussed further in section 5.4 below) - this may indicate that the cross-border acquisitions are driven by managerial factors rather than the pursuit of the maximization of shareholder wealth.

\section{Target Company Cross-Border Effects - Prior Empirical Evidence}

The literature on domestic mergers and acquisitions in the UK (e.g., Franks and Harris (1989) and Limmack (1991)) as well as in other markets (such as e.g., Jensen and Ruback (1983) and Franks et al. (1991) for the US) invariably indicate that large abnormal returns accrue to target company shareholders. Although one would expect target shareholders to gain significantly also in cross-border acquisitions, the level of such gains may, as explained in the previous section, be systematically different from those associated with domestic acquisitions.

For the US market, positive target company cross-border effects are found by e.g., Tessema (1985), Harris and Ravenscraft (1991), Shaked et al. (1991), Cebenoyan et al. (1992), Kang (1993), Marr et al. (1993), Swenson (1993), and Cheng and Chan (1995), although Dewenter (1995) do not find the abnormal returns to US target shareholders to be systematically different in domestic and cross-border acquisitions once industry-effects are controlled for. Similarly, Wansley et al. (1983) find the cross-border effect to disappear, once the analysis is restricted to cash financed conglomerate acquisitions.

Conn and Connell (1990) and Feils (1993), analyzing the abnormal returns in crossborder mergers between US and UK companies, find the gains to UK targets to be only about half as large as those observed for US targets. However, neither Conn and Connell nor Feils analyze UK target companies in domestic acquisitions, and are thus unable to comment upon the nature of any target company cross-border effect in the UK.

Prior studies tend to find US target shareholders to gain more in cross-border than 
in domestic acquisitions. However, there is at least some evidence to suggest that the target company cross-border effect may be attributable to differences in the characteristics of domestic and cross-border acquisitions, rather than to fundamental differences in the level of abnormal returns associated with domestic and overseas acquirors per se (Wansley et al. (1983) and Dewenter (1995)). In addition, the low level of abnormal returns to target shareholders in cross-border acquisitions into the UK (as reported by Conn and Connell (1990) and Feils (1993)), may suggest that the presence of a similar target cross-border effect in the UK is unlikely. In this paper we explicitly test whether the level of abnormal returns to shareholders in listed UK companies targeted in cross-border and domestic acquisitions are systematically different. In addition, we test whether target company abnormal returns in cross-border acquisitions is associated with international risk diversification, market access or exchange rate effects, or whether any cross-border effect is associated with differences in the characteristics of domestic and cross-border acquisitions.

\section{Data Sources and Methodology}

This paper contains an analysis of 116 cross-border and 514 domestic takeover bids for listed UK companies made on or after 1 January 1986 and for which the bid outcome was known prior to the end of December $1991^{2}$. Information as to what takeover bids took place, the name of the bidding and target companies, the nationality of the bidder, the bid outcome, whether or not the bid was competitive or revised, the form of payment offered, the percentage stake by the bidding company in the target at the time of the bid announcement (the toehold), the industry of the target company, and whether the acquisition was horizontal, vertical or conglomerate, was obtained from Acquisitions Monthly, while exchange rate data was obtained from Datastream. Acquisitions Monthly, as well as Financial Times news stories around the time of the bid announcement, were searched in order to ascertain whether the initial offer by the bidder received a hostile reception from the target company board of directors. A wide variety of sources were searched (including company accounts, Datastream, Global Access, Extel, Financial Times, Sequencer, as well as letters to several companies) for data on whether the overseas acquiring companies had either UK or EU operations prior to the time of the acquisition. Market capitalizations of equity were obtained from the London Business School Risk Measurement Service (edited by Dimson and Marsh) ${ }^{3}$, while monthly log returns were obtained from the London Business School Share Price Database.

For the majority of the bidding companies, the classification of nationality used by Acquisitions Monthly (which classifies the bidding companies according to where they, or their mother companies if the bidding company is a subsidiary, have their registered office) is adopted in this paper. However, where the bidding company is not listed in its home market but listed elsewhere, the nationality of the bidder is reclassified to the country of the main stock market listing of the company ${ }^{4}$.

While the market model is the most widely used event study model, prior research by Connell and Conn (1993) and Gregory (1997) suggests the assumptions of stationary $\alpha$ and $\beta$ values are questionable. Due to the difficulties in establishing the appropriate benchmark, these and other researchers advocate the application of several test models in 
the analysis of mergers and acquisitions, as the choice of model may influence the results obtained. In addition, studies such as Kennedy and Limmack (1996), Gregory (1997) and Higson and Elliott (1998) suggest that controlling for the commonly observed size effect in the return generating process may be of particular importance in studies of mergers and acquisitions, as target companies tend to be small.

In this study, two such size-adjusted benchmarks are applied in addition to three more conventional models. The size-deciles (SD) control model compares the return on the share to a benchmark derived from a portfolio of companies with similar market capitalization to the company in question. The size deciles are constructed using monthly log return data for all UK companies available from Datastream during each month, with annual rebalancing of the decile constituents. Target companies are matched with the appropriate size decile returns based on the pre-bid market value of the target. The HoareGovett small companies model is a variant of the capital asset pricing model including both the overall market index and a stock market index for small capitalization companies in the benchmark. The other three test models applied in this study are the index model (IM), the market model (MM) and the capital asset pricing model (CAPM). As the five different test models are generally found to produce similar levels of abnormal returns, for brevity we report only the results for the size deciles and the market model. Our main focus is on the results from the size deciles model, which has a larger sample size than some of the traditional models, and the added benefit of controlling for stock market size effects. However, given that most previous studies have tended to focus on the market model, for completeness we also report the abnormal returns for this model. The size deciles and market models are specified as follows ${ }^{5}$ :

$\begin{array}{ll}\text { SD: } & \mathrm{R}_{\mathrm{it}}=\mathrm{R}_{\mathrm{SDt}}+\mu_{\mathrm{it}} \\ \mathrm{MM}: & \mathrm{R}_{\mathrm{it}}=\alpha_{\mathrm{i}}+\beta_{\mathrm{i}} \mathrm{R}_{\mathrm{mt}}+\mu_{\mathrm{it}}\end{array}$

where $\mathrm{R}_{\mathrm{it}}$ refers to the return on the share (calculated as $\log _{\mathrm{e}}\left[\left(\mathrm{P}_{\mathrm{it}}+\mathrm{D}_{\mathrm{it}}\right) / \mathrm{P}_{\mathrm{it}-1}\right]$, with $\mathrm{P}_{\mathrm{it}}$ referring to the share price at time period $t$ and $\mathrm{D}$ to dividends), $\mathrm{R}_{\mathrm{SDt}}$ the equally weighted return on the deciles portfolio of companies with similar market values to the company being analyzed, $R_{m}$ the return on the Financial Times Actuaries index for the UK market, $\alpha_{i}$ and $\beta_{\mathrm{i}}$ are regression coefficients, and $\mu_{\mathrm{it}}$ the error term (the estimated abnormal return during the analysis period). The market model parameters (as well as those for the CAPM and HGSC) have been estimated on a minimum of 30 observations during the period from t-68 to t-9, where time periods refer to months relative to the month of the bid announcement. Due to the additional data requirements for the market model compared to the size deciles model, the market model sample is reduced to 389 domestic and 96 crossborder transactions.

This study adopts a fairly long analysis period, stretching from month t-8 to $t+5$, although, as discussed further below, in the cross-sectional analyses we focus on shorter windows surrounding the month of the bid announcement. Previous studies (e.g., Franks et al. (1977) and Limmack (1991)) have found that target company share prices tend to rise several months prior to bid announcements. Adopting a long pre-bid analysis period may allow us to establish whether the pattern of share price performance leading up to the bid differs between domestic and cross-border acquisitions, and to analyze whether the pre-bid 
performance of target companies differ depending on whether the bidding company is based in the UK or abroad.

The inclusion of the post-bid period allows the capture of later price reactions in the context of the UK merger timetable regulations, which may allow the bid process to extend over several months. Post-bid data thus allows for an analysis of the impact of bid revision and bid outcome.

The level of statistical significance of the equally weighted cumulative abnormal returns is tested using the cross-sectional $t$-test (Strong (1992)) ${ }^{6}$. The differences in abnormal returns in cross-border and domestic acquisitions is tested using a two-sample difference in mean $t$-test (Weiss and Hassett (1986)).

\section{Analysis of Results}

\section{1. $\quad$ Target Company Shareholders in Domestic Acquisitions}

The average abnormal returns to the listed UK companies targeted in 514 domestic acquisitions during the 1986-1991 period, are detailed in the second and third columns of Table 1 for the size deciles and market model, respectively. As can be seen from this table, targets in domestic acquisitions substantially under-perform during the pre-bid period, with negative abnormal returns in every month from t-8 to t-3. It is inappropriate to directly attribute these large negative abnormal returns during the pre-bid period - amounting to a highly significant $-9.04 \%$ with the size deciles model, or $6.51 \%$ with the market model - to the forthcoming bid announcements. A more plausible explanation is that bidding companies target companies with at least a short-term history of poor share price performance. Insignificant abnormal returns are observed for month $\mathrm{t}-2$, while during $\mathrm{t}-1$ and $t$, significant positive abnormal returns accrue to target shareholders in domestic UK acquisitions. The abnormal return during the month of the bid announcement amounts to a highly significant $18.76 \%$ with the size deciles model, or $20.29 \%$ with the market model. Targets tend to encounter small negative abnormal returns during the months following the bid announcement, with cumulative abnormal returns during the post-bid period $(t+1, t+5)$ amounting to a highly significant $-1.85 \%$ with the size deciles model. While negative ($1.27 \%$ ), the post-bid abnormal returns are not significant for the market model. Still, whether the analysis is based on short or long event windows, and regardless of which test model is applied, target shareholders in domestic UK acquisitions are found to gain significantly around the time of the bid announcement.

Table 1 about here

\section{2. $\quad$ Target Company Shareholders in Cross-Border Acquisitions}

The average abnormal returns to UK target companies in 116 cross-border acquisitions into the UK are given in the fourth and fifth columns of Table 1. As is the case with target companies in domestic acquisitions, cross-border targets also, on average, under-perform during the period from t-8 to t-3. However, in the case of cross-border targets, large positive abnormal returns are observed as early as two months prior to the bid announcement, although these are not significant with the market model. The large pre-bid abnormal returns in cross-border acquisitions highlight the potential limitation of several 
previous studies such as Tessema (1985), Feils (1993), and Eun et al. (1996), which apply short event windows to the analysis of abnormal returns to targets in cross-border acquisitions.

During the month of the bid announcement, the average abnormal return amounts to a highly significant $19.60 \%$ with the size deciles model, or $21.05 \%$ with the market model. Positive abnormal returns are also observed for the month following the bid announcement (although not significant with the market model), while negative abnormal returns are observed for months $t+3$ and $t+4$. The post-bid abnormal returns are, however, generally small. The cumulative abnormal returns for the overall post-event period $(t+1, t+5)$ are marginally positive (negative) for the size deciles (market) model, although not significant with either model.

\section{3. $\quad$ Target Company Cross-Border Effects}

The differences in the average abnormal returns to shareholders in the 116 crossborder and 514 domestic acquisitions are given in the final two columns of Table 1. As discussed above, UK target companies in both cross-border and domestic acquisitions significantly under-perform over the period from t-8 to t-3. The differences in abnormal returns during these pre-bid months are small and not statistically significant.

During the month of the bid announcement, there is a small positive cross-border effect of 0.84 percentage points with the size deciles model, or 0.76 percentage points with the market model, although these differences in abnormal returns between domestic and cross-border acquisitions are not statistically significant. However, UK targets in crossborder acquisitions gain more than target shareholders in domestic transactions during the months leading up to the bid, as well as during the months after the bid announcement. While the differences in abnormal returns are significant with the size deciles model, only the cross-border effect for month t-1 is significant for the smaller market model sample.

The appropriate event window for analyzing the effect on shareholder returns of mergers and acquisitions is controversial. Short windows may not capture the full effect of the transaction if there is bid leakage or if price sensitive information is released after the initial bid announcement (e.g., the announcement of bid outcome, bid revision, or the entry of other companies in the bidding contest). On the other hand, long windows may introduce noise. In this paper, we focus mainly on the bid month, although we also include two slightly longer event windows ( $t$ to $t+1$, and $t-2$ to $t+1$ ) in the cross-sectional analysis. As can be seen from Table 1, the cumulative abnormal returns are significantly higher in cross-border than in domestic acquisitions for the extended event window, although the two-month window is only significant with the size deciles model. Over the four-month period from $t-2$ to $t+1$, the cumulative cross-border effect is a highly significant 10.07 percentage points with the size deiles model (6.98 percentage points with the market model), with cumulative abnormal returns of $30.71 \%$ (31.35\%) in cross-border compared to $20.64 \%$ (24.37\%) in domestic acquisitions. In order to test whether the cross-border effect persists once differences in the characteristics of domestic and cross-border acquisitions are controlled for, we include these longer event-windows in the cross-sectional analysis. Given the levels of abnormal returns are overall similar between the size deciles and market models, we focus on the size deciles model in the cross-sectional regressions, due to the larger sample size available for this model. 


\subsection{Cross-Sectional Analysis}

Previous studies have identified a number of acquisition characteristics, which influence the level of target company premia. It is possible that the cross-border effect reported above simply reflects the different characteristics of companies targeted by domestic and foreign bidders or the nature of the bids (Lessard (1993)). In addition, Dewenter (1995) find “... that the market's reaction to buyer nationality is closely tied to the transaction's characteristics”. (p. 421). The bid characteristics are discussed below and are subsequently included in the return models as control variables. Summary statistics for the cross-sectional variables included in this study are given in Table $2^{7}$.

Table 2 about here

(i) Payment. In cash-only acquisitions, target shareholders become immediately liable for capital gains tax (CGT) on any inflation-adjusted capital gain above the annual tax-free threshold, while if the payment is in loan stock, the CGT becomes payable when the loan is repaid (or the loan stock disposed of). In equity bids, no CGT would usually be payable at the time of the acquisition, but rather when the new shares in the bidding company are disposed of. Consequently, in order to compensate for the tax effect, it can be hypothesized that target shareholders will demand a higher takeover premium in cash than in equity offers (Davidson and Cheng (1997)). Indeed, prior studies such as Wansley et al. (1983), Huang and Walkling (1987), Franks et al. (1988), Harris and Ravenscraft (1991) and Sudarsanam et al. (1996) find target shareholders to gain more in acquisitions with cash than with equity offers.

However, as argued by Davidson and Cheng (1997), cash bids also “...reduce the asymmetric information problem that would be created in an exchange of common stock" (p. 465). Travlos (1987), Wansley et al. (1987), Franks et al. (1988), Servaes (1991) and Agrawal et al. (1992) all find bidding shareholders to experience negative abnormal returns following equity financed acquisitions $^{8}$. If target shareholders receive payment in the form of shares in the bidder, these negative returns on bidding company shares may result in low abnormal returns to target shareholders.

A simple dichotomy between cash and equity bids may not suffice, however, as investors may react differently to cash offers with and without loan note alternatives, due to the differential tax treatments of cash and loan notes. In addition, investors may prefer offers giving them a choice with regard to the form of payment. The payment effect is analyzed based on five categories of cash only, cash with full loan note alternative, equity only, equity with full cash alternative, and all other hybrid forms of payment grouped together in a residual fifth category.

A significantly higher proportion of cross-border than domestic acquisitions are cash offers. This may be because target shareholders are reluctant to receive payment in shares of overseas companies, at least if these are not listed in the UK. If investors respond more favorably to cash than to equity offers, the cross-border effect may be attributable to such a payment effect. 
(ii) Hostile acquisitions. Studies by Jensen and Ruback (1983), Jarrell et al., (1988), Franks and Harris (1989) and Franks and Mayer (1996), find target shareholders to gain more in hostile as compared to uncontested acquisitions. In addition, Dewenter (1995) find "Foreign investors pay more than domestic investors in hostile transactions...”. (p. 421). In the cross-sectional analysis, we introduce a 0-1 dummy variable taking the value 1 where the initial offer by the bidder was rejected by the target board. However, given that there is no significant difference in the proportion of domestic and cross-border bids which are hostile, bid hostility is unlikely to account for the target company cross-border effect.

(iii) Competitive bids. Studies such as Michel and Shaked (1986), Stulz et al. (1990), Kaplan and Weisbach (1992) and De et al. (1996) for domestic US acquisitions, and Swenson (1993) for cross-border acquisitions, find US targets to gain substantially more in competitive than in single bidder takeovers contests. Dewenter (1995) finds target shareholders to gain marginally more in competitive bids, although not significantly so. In the UK market, Sudarsanam et al. (1996) find, rather surprisingly, target shareholders to gain marginally less where there were multiple bids. However, all extant research points to a competition effect and so a $0-1$ dummy is introduced into the model, taking the value 1 in competitive bids. There is no significant difference in the proportion of domestic and crossborder bids which are competitive.

(iv) Bid revision. Franks and Harris (1989) find UK target shareholders to gain significantly more in revised bids, although Limmack (1991) for UK acquisitions and De et al. (1996) for the US find bid revision to have relatively little impact on the level of abnormal returns to targets. Again a 0-1 dummy is introduced into the model to control for this potential factor in the target company premium. However, as approximately the same proportion of domestic and cross-border offers are revised, bid revision is unlikely to account for any cross-border effect.

(v) Outcome. Jensen and Ruback (1983) observe that although the level of abnormal returns to target shareholders in failed acquisitions is at least as high as that of successful acquisitions at the time of the bid, target shareholders experience negative abnormal returns on the announcement of the unsuccessful bid outcome. A 0-1 dummy is introduced, taking the value 1 if the bidder failed to gain control. While a slightly higher proportion of domestic than cross-border offers fail, the difference is not statistically significant.

(vi) Industry. In their analysis of cross-border acquisitions into the US, Cakici et al., (1991) find the level of abnormal returns to be significantly higher in acquisitions within the manufacturing and oil \& gas sectors than for other industries. Contrary to the majority of US studies uncovering large target cross-border effects, Dewenter (1995) finds no cross-border effects within the US chemical and retail industries. Controlling for industry classification may therefore be of importance in the analysis of abnormal returns in domestic and cross-border acquisitions. We classify the target companies into four broad industrial groups, as detailed in Table 2. As is evident from this table, there are significant differences in the industry groupings of domestic and cross-border takeover targets. In particular, a higher proportion of domestic than cross-border acquisitions are of UK companies operating within the 
services sectors, while cross-border acquisitions more commonly involve information technology \& financial firms.

(vii) Related. As argued by Datta and Puia (1995), whether the acquisition is horizontal, vertical or conglomerate may have an impact on the level of operating synergies, and possibly also on the level of abnormal returns associated with the merger. While Wansley et al. (1983) find US targets to gain more in cross-border than in domestic acquisitions, the cross-border effect is no longer significant when the analysis is restricted to cash financed conglomerate acquisitions. Splitting their sample into horizontal, vertical and conglomerate acquisitions, Cakici et al. (1991) find US targets in cross-border acquisitions to gain marginally more in conglomerate than in other types of acquisitions. We follow Cakici et al., and similarly classify our sample into three groups based on the relatedness between the industries of the target and bidding companies. A significantly lower proportion of cross-border than domestic bids is conglomerate, with correspondingly a higher proportion of cross-border bids being horizontal.

(viii) Bid toehold. The prior evidence with regard to the effect of bidder toehold on target returns is rather mixed. While Sudarsanam et al. (1996) find pre-bid toeholds to have a significant negative impact on the level of abnormal returns to UK targets, Franks and Harris (1989) find UK targets to gain more when the bidding company hold a large stake prior to the bid announcement. The percentage holding in the target by the bidder at the time of the bid announcement is used as the control variable. Pre-bid stakes tend to be significantly higher in cross-border than in domestic acquisitions, and we analyze the impact of toeholds in the crosssectional regressions below.

(ix) Size. As discussed above, the size effect may cause the observed return to be a function of the market value of the company. In acquisitions, it is also possible that bidding companies can afford to be comparatively more generous with small targets, thus paying a higher premium to small than to larger target companies. Indeed, Peterson and Peterson (1991) argue that “...smaller [US] target firms receive greater absolute returns...”. (p. 401). Consequently, in addition to applying size-adjusted models, a size variable (the log of the pre-bid market value of the target) is included in the cross-sectional analysis in order to analyze whether target company abnormal returns are dependent on the size of the company ${ }^{9}$. Target companies tend to be larger in cross-border than in domestic acquisitions, and we control for this in the cross-sectional analysis.

\subsubsection{Cross-Sectional Analysis of Abnormal Returns in Cross-Border Acquisitions}

In this section, three hypotheses as to why a target company cross-border effect may be present are tested: the international diversification hypothesis, the market access hypothesis, and the exchange rate hypothesis. We test these hypotheses in cross-sectional analyses of target returns in cross-border acquisitions. The results are reported in Table 3. Given the potential impact of company characteristics on the level of target abnormal returns, we control for various bid characteristics, as discussed in the previous section.

Table 3 about here 
Location of cross-border bidder and international diversification. It can be hypothesized that the degree of international diversification benefit from cross-border acquisitions into the UK will vary with the location of the overseas bidder. The international diversification hypothesis is tested by analyzing whether the level of gains to target shareholders in cross-border acquisitions is dependent upon whether the bidding company is based within the EU, in other European countries, in the US, or in other overseas countries. If bidders are willing to pay high prices for international diversification, we would expect UK targets to gain more in acquisitions by either US or 'rest of the world' bidders than from intra EU or European acquisitions.

As can be seen from Table 3, target abnormal returns are somewhat larger in acquisitions by companies based outside of Europe than in intra-European cross-border acquisitions. In particular, the coefficient for 'rest of the world' is positive and significant for the $t$ to $t+1$ event window, although the coefficients are not significant for either the bid month itself or for the longer $\mathrm{t}-2$ to $\mathrm{t}+1$ event window. There is thus only limited support for the international risk diversification hypothesis.

Market access. The takeover bids analyzed in this study took place during the time period between the passing of the Single European Act and the introduction of the Single European Market. A large proportion of the cross-border bids appears to have been undertaken in order to gain access to the European Market, and it can be hypothesized that the cross-border effect will depend on whether or not the bidder has operations in either the UK or in other EU member states prior to the cross-border acquisition. We test two aspects of the market access hypothesis: Firstly, we test the UK market access hypothesis. We introduce two 0-1 dummy variables, with 'prior UK operations' taking the value 1 where the overseas acquiring company has operations in the UK prior to the time of the bid announcement and zero otherwise, and the 'no prior UK operations' dummy taking the value 1 where the acquisition represent a new entry into the UK market and zero otherwise. Unfortunately, despite the use of numerous data sources, sufficient information to verify whether the overseas acquiring company had prior UK (or EU) operations was not available for all transactions. The unclassified bids are left as a third residual category ${ }^{10}$.

Secondly, we test the EU market access hypothesis. We introduce another two 0-1 dummy variables capturing the presence of prior EU (including UK) operations prior to the bid announcement. If overseas bidders are willing to pay high premia for market access, we would expect the dummy variables for 'no prior operations' in the UK or the EU to be positive, and possibly the coefficient for 'prior operations' to be negative ${ }^{11}$.

While the negative (but insignificant) coefficients for prior UK operations may appear to lend some support to our market access hypothesis, this is contradicted by the coefficients for the 'no prior UK operations' dummies, which are also negative (although again not statistically significant). There are no significant differences between the coefficients for the presence and absence of prior UK operations. There is thus no support for a UK market access hypothesis.

While the coefficients for the 'no prior EU operations' are positive, as hypothesized, none of the coefficients are statistically significant. However, rather surprisingly, we observe larger and - for the bid month statistically significant - positive coefficients for the 'prior EU operations' dummies. This suggests that bidders with prior 
EU operations paid higher prices for their UK targets than did bidders without a EU presence, although the coefficients are not significant for the longer event window. The positive coefficient for prior EU operations is contrary to the EU market access hypothesis, which we therefore reject. There is no evidence of the level of target company returns in cross-border acquisitions being positively related to acquiring companies seeking either UK or EU market access.

Exchange rate. As argued in the theoretical framework, it can be hypothesized that UK target shareholders will gain more when Sterling is relatively weak against the currency of the overseas bidding company, although the prior evidence is rather mixed. The exchange rate variable measures the deviation in the exchange rate between Sterling and the home currency of the overseas acquiring company during the month of the bid announcement from the mean exchange rate during the previous two years. The mean exchange rate variable (as reported in Table 2) of 0.0083 is somewhat puzzling, indicating that the cross-border acquisitions generally take place when the currency of the acquiring company is marginally weak (relative to previous levels) against Sterling. As reported in Table 3, the coefficient for the exchange rate variable is positive, indicating that UK targets gain marginally more when Sterling is relatively strong, contrary to the predictions of the exchange rate effect hypothesis. However, the coefficients are not statistically significant for any of the event windows.

The analysis above indicates that the level of abnormal returns in cross-border acquisitions do not appear to be driven by international diversification, market access or exchange rate effects.

The overall explanatory powers of the regressions are low, with the adjusted $\mathrm{R}^{2}$ ranging between $0.3 \%$ and $6.1 \%$, and none of the regressions are overall statistically significant. However, a few of the variables are significant, at least for some event windows, indicating that the level of abnormal returns may depend on the characteristics of the bid. The industry of the target firm, as well as the industrial relatedness between the target and the bidder, appears to have some impact on the level of abnormal returns to target shareholders in cross-border acquisitions. Targets within the IT \& financials sectors are found to gain somewhat less than other targets, and targets gain somewhat more in vertical than in either horizontal or conglomerate acquisitions. However, the regression coefficients are not significant for all event windows and the results are not robust.

None of the regression coefficients for bid hostility, competitive bids, the size of the pre-bid stake or company size are found to be significant. Although the abnormal returns are marginally higher in cash bids (and in particular those with a loan note alternative) than in offers with other forms of payment, the coefficients are generally not significant. The evidence of a payment effect being present in cross-border acquisitions is thus weak ${ }^{12}$.

\subsubsection{Cross-Sectional Analysis of the Cross-Border Effect}

In the previous section we established that bid specific variables explain some of the cross-sectional variation in the level of target abnormal returns. In order to test whether these bid characteristics account for the target company cross-border effect, we repeat the cross-sectional analysis for the whole sample of cross-border and domestic acquisitions, with a cross-border dummy (taking the value 1 in cross-border acquisitions) added to the explanatory variables. These results are reported in Table 4. 
All of the regressions are overall significant, although the explanatory power of the regressions - particularly for the two short event windows - are low, with adjusted $\mathrm{R}^{2}$ of $2.2 \%$ and $3.5 \%$ the $t$ and $t$ to $t+1$ event windows, respectively. The explanatory power for the longer event window of $t-2$ to $t+1$ is better, as reflected by the adjusted $\mathrm{R}^{2}$ of $8.8 \%$. Overall, shareholders in the UK, particularly over the longer event window, tend to gain more from cash bids with full loan note alternatives or from competitive bids, than they do from other offers. Conversely, the levels of target abnormal returns are significantly lower in equity-only offers or failed acquisitions than they are after other bids. This is consistent with prior research (e.g., Franks et al. (1988) and Harris and Ravenscraft (1991)). While positive coefficients (significant for the long event window) are observed for cash offers with loan note alternatives, insignificant coefficients are observed for cash-only bids. The results may relate to the different tax implications of such offers, with shareholders preferring loan notes to cash, due to their more favorable tax treatment (Sudarsanam (1995)).

The analysis of bid hostility, competitiveness, revision and outcome is complicated by the fact that these variables are all significantly positively correlated ${ }^{13}$. While the regressions reported in Table 4 include all four variables, regressions with all possible combinations of the four variables included/excluded were undertaken for robustness checks. The results vary somewhat depending on the event window used as well as on the combination of explanatory variables included in the analysis, indicating some problems of colinearity between these variables. Consistent with our expectations, we find UK targets to gain more - particularly over the longer event windows - in competitive than in single bidder contests, and less in failed than in successful acquisitions. Bid hostility and bid revision - while significant if tested independently - are found not to have a significant impact on the levels of target company abnormal returns once the presence of multiple bidders and bid outcome are also controlled for.

Neither the size of the pre-bid stake, nor the size of the target firm, appears to have a significant impact on the levels of abnormal returns to UK targets. Similarly, none of the industry or industry relatedness variables are statistically significant.

While some of the cross-sectional variables are significant, none of the 'crossborder' dummy variables are significant. There is thus no evidence of a residual crossborder effect being present in the UK once pay and other company and bid characteristics are controlled for. Indeed, once we control for such characteristics, the target company cross-border effect during the month of the bid announcement (or over the two-month period from $t$ to $t+1$ ) reverse sign, from an insignificant +0.84 percentage points (a significant +4.04 ), to an insignificant -2.56 percentage points (insignificant -0.21 ). Similarly, for the four-month event window of $t-2$ to $t+1$, the cross-border effect is reduced from a highly significant +10.07 percentage points, to an insignificant +3.26 . The target company cross-border effect thus appears to be attributable largely to differences in the characteristics of domestic and cross-border acquisitions and the impact of such bid and company characteristics on the level of target company abnormal returns. Once we control for the impact of bid characteristics - in particular the method of payment offered - there is 
no evidence of a significant residual target company cross-border effect in the UK, regardless of whether the analysis is based on the bid month, or whether longer event windows surrounding the bid announcement are applied.

\section{Summary and Conclusions}

This paper analyzes the abnormal returns to target company shareholders in 116 cross-border and 514 domestic takeover bids for UK listed companies during the 19861991 period. During the t-8 to t-3 (where t refers to the month of the bid announcement) period, target shareholders in both domestic and cross-border acquisitions suffer negative abnormal returns, indicating that target companies tend to under-perform prior to the bid announcement.

During the month of the bid announcement, large and highly significant abnormal returns accrue to shareholders in both domestic and cross-border targets, amounting to a highly significant $18.76 \%$ (20.29\%) with the size deciles model (the market model) for targets in domestic acquisitions, and 19.60\% (21.05\%) for UK targets acquired by foreign firms. The target company cross-border effect during the month of the bid announcement is small, at 0.84 (0.76) percentage points, and not statistically significant. However, over the four month period from $\mathrm{t}-2$ to $\mathrm{t}+1$, UK target shareholders gained a highly significant 10.07 (6.98) percentage points more in cross-border than in domestic acquisitions, with cumulative abnormal returns of $30.71 \%$ (31.35\%) in cross-border compared to $20.64 \%$ (24.37\%) in domestic acquisitions.

The level of abnormal returns to target shareholders in cross-border acquisitions is found to be somewhat higher in bids by companies based outside Europe or the US, although the coefficients are only significant for the two-month event window. None of the other dummy variables for bidder location are significant. We therefore find only limited support for an international diversification effect premium. The target premium in crossborder acquisitions appears not to be significantly influenced by whether or not the bidder had prior UK operations. There is thus no evidence to support a UK market access premium. Rather surprisingly, we find a negative EU market access premium, with UK targets gaining more in acquisitions by bidders who already had prior EU operation. This is inconsistent with the market access hypothesis, which we therefore reject. Finally, we find no support for the exchange rate hypothesis, whereby target returns would depend on the strength of the currency of the overseas acquiring company.

The target company cross-border effect, however, appears to be attributable largely to differences in the characteristics of domestic and cross-border acquisitions, and the impact of company and bid characteristics on the level of target abnormal returns. Indeed, the level of abnormal returns is found to depend significantly on the bid characteristics, in particular the method of payment. Target shareholders gain significantly less in equity offers, and somewhat more in cash offers with loan note alternatives. As a significantly higher (lower) proportion of domestic than cross-border acquisitions are equity (cash) offers, this appears to account for most of the target company cross-border effect.

Other bid characteristics, including bid outcome and whether or not the bid was competitive, are also found to have a significant impact on the cross-sectional variation in the level of abnormal returns. Once bid characteristics are controlled for, the bid month cross-border effect with the size deciles model reverses sign to -2.56 percentage points, 
while for the longer event period from $t-2$ to $t+1$ months, the cross-border effect is reduced to an insignificant +3.26 percentage points. The cross-border effect thus appears to be attributable largely to differences in the bid characteristics of domestic and cross-border acquisitions. There is no evidence of a residual target company cross-border effect being present in the UK once the method of payment and other bid characteristics are controlled for. 


\section{References}

Acquisitions Monthly (1986-1991), Tables on Acquisitions of UK Listed Companies, (Tudor House Publications).

Agrawal, A., J.F. Jaffe and G.N. Mandelker (1992), `The Post-Merger Performance of Acquiring Firms: A Re-examination of an Anomaly', Journal of Finance, Vol. 47, No. 4 (September), pp. 1605-1621.

Bliss, R.T. and R.J. Rosen (2001), 'CEO Compensation and Bank Mergers', Journal of Financial Economics, Vol. 61, pp. 107-138.

Bodnar, G., C. Tang and J. Weintrop (1997), Both Sides of Corporate Diversification: The Value Impacts of Geographic and Industrial Diversification, NBER Working Paper, No. W6224.

Cakici, N., C. Hessel and K. Tandon (1991), 'Foreign Acquisitions in the United States and the Effect on Shareholder Wealth’, Journal of International Financial Management and Accounting, Vol. 3, No. 1, pp. 39-60.

Cebenoyan, A.S., G.J. Papaioannou and N.G. Travlos (1992), 'Foreign Takeover Activity in the U.S. and Wealth Effects for Target Firm Shareholders’, Financial Management, Vol. 21, Iss. 3 (Autumn), pp. 58-68.

Cheng, L.T.W. and K.C. Chan (1995), 'A Comparative Analysis of the Characteristics of International Takeovers’, Journal of Business Finance \& Accounting, Vol. 22, No. 5, pp. 637-657.

Choi, F.D.S. and C. Lee (1991), 'Merger Premia and National Differences in Accounting for Goodwill', Journal of International Financial Management and Accounting, Vol. 3, No. 3, pp. 219-240.

Conn, R.L. and F. Connell (1990) 'International Mergers: Returns to U.S. and British Firms', Journal of Business Finance \& Accounting, Vol. 17, No. 5, Winter, pp. 689-711.

Connell, F. and R.L. Conn (1993), ‘A Preliminary Analysis of Shifts in Market Model Regression Parameters in International Mergers Between US and British Firms: 1970-1980’, Managerial Finance, Vol. 19, No. 1, pp. 47-77.

Danbolt, J., (1995), 'An Analysis of Gains and Losses to Shareholders of Foreign Bidding Companies Engaged in Cross-Border Acquisitions Into the United Kingdom - 1986-1991', European Journal of Finance, Vol. 1, No. 3, pp. 279-309.

---- (1996), A Comparative Analysis of the Wealth Effects to Target and Bidding Company Shareholders from Domestic and Cross-Border Acquisitions into the United Kingdom (1986-1991), PhD Thesis (HeriotWatt University).

Datta, D.K. and G. Puia (1995), 'Cross-Border Acquisitions: An Examination of the Influence of Relatedness and Cultural Fit on Shareholder Value Creation in U.S. Acquiring Firms’, Management International Review, Vol. 35, pp. 337-359.

Davidson, W.N. and L.T.W. Cheng (1997), 'Target Firm Returns: Does the Form of Payment Affect Abnormal Returns?’, Journal of Business Finance \& Accounting, Vol. 24, No. 3 and 4, pp. 465-479.

Davis, E.P. (1991), 'International Diversification of Institutional Investors', Bank of England Discussion Papers, Technical Series, No. 44 (September), pp. 10-16.

De, S., M. Fedenia and A.J. Triantis (1996), 'Effects of Competition on Bidder Returns', Journal of Corporate Finance, Vol. 2, pp. 261-282.

Dewenter, K.L. (1995), 'Does the Market React Differently to Domestic and Foreign Takeover Announcements? Evidence from the U.S. Chemical and Retail Industries', Journal of Financial Economics, Vol. 37, pp. 421-441.

Dimson, E. and P. Fraletti (1986), 'Brokers' Recommendations: The Value of a Telephone Tip', The Economic Journal, Vol. 96, pp. 139-159.

Department of Trade and Industry (DTI) (1991), Competition Policy - How it Works, HMSO.

Eun, C.S., R. Kolodny and C. Scheraga (1996), 'Cross-Border Acquisitions and Shareholder Wealth: Tests of the Synergy Hypothesis’, Journal of Banking \& Finance, Vol. 20, pp. 1559-1582.

Fatemi, A.M. (1984), 'Shareholder Benefits from Corporate International Diversification', Journal of Finance, Vol. 39, No. 5, December, pp. 1325-1344.

---- and E.P.H. Furtado (1988), ‘An Empirical Investigation of the Wealth Effects of Foreign Acquisitions', in S.J. Khoury and A. Ghosh (Ed.), Recent Developments in International Banking and Finance, Vol. 2, Lexington Books, pp. 363-379.

Feils, D.J. (1993), Shareholder Wealth Effects of International Mergers and Acquisitions: Evidence from the United States, the United Kingdom, and Germany, PhD Thesis (University of South Carolina).

Firth, M. (1991), 'Corporate Takeovers, Shareholder Returns and Executive Rewards', Managerial and Decision Economics, Vol. 12, pp. 421-428.

Franks, J.R., J.E. Broyles and M.J. Hecht (1977), 'An Industry Study of the Profitability of Mergers in the United Kingdom’, Journal of Finance, Vol. 32, No. 5, December, pp. 1513-1525.

---- and R.S. Harris (1989), 'Shareholder Wealth Effects of Corporate Takeovers - The UK Experience 19551985’, Journal of Financial Economics, Vol. 23, pp. 225-249.

----, R.S. Harris and C. Mayer (1988), 'Means of Payment in Takeovers: Results for the United Kingdom and the United States’, in A.J. Auerbach.(Ed.), Corporate Takeovers: Causes \& Consequences, University of Chicago Press, Chicago, pp. 221-263. 
----, R.S. Harris and S. Titman (1991), 'The Post-Merger Share-Price Performance of Acquiring Firms', Journal of Financial Economics, Vol. 29, pp. 81-96.

----and C. Mayer (1996), 'Hostile Takeovers and the Correction of Managerial Failure', Journal of Financial Economics, Vol. 40, pp. 163-181.

Froot, K.A. and Stein, J.C. (1991), 'Exchange Rates and Foreign Direct Investment: An Imperfect Capital Markets Approach’, Quarterly Journal of Economics, Vol. 106, pp. 1191-1217.

Geroski, P. and A. Vlassopoulos (1990), 'European Merger Activity: A Response to 1992?', in Continental Mergers are Different: Strategy and Policy for 1992, Center for Business Strategy (London Business School), pp. 22-46.

Gregory, A. (1997), ‘An Examination of the Long Run Performance of UK Acquiring Firms', Journal of Business Finance \& Accounting, Vol. 24, No. 7\&8, pp. 971-1002.

Harris, R.S. and D. Ravenscraft (1991), 'The Role of Acquisitions in Foreign Direct Investment: Evidence from the U.S. Stock Market', Journal of Finance, Vol. 46, No. 3 (July), pp. 825-844.

Higson, C. and J. Elliott (1998), 'Post-Takeover Returns: The UK Evidence', Journal of Empirical Finance, Vol. 5, No. 1, pp. 27-46.

Hisey, K.B. and R.E. Caves (1985), 'Diversification Strategy and Choice of Country: Diversifying Acquisitions Abroad by U.S. Multinationals, 1978-1980’, Journal of International Business Studies, Vol. 15 (Summer), pp. 51-64.

Huang, Y.S. and R.A. Walkling (1987), 'Target Abnormal Returns Associated with Acquisition Announcements - Payment, Acquisition Form, and Managerial Resistance’, Journal of Financial Economics, Vol. 19, pp. 329-349.

Hymer, S.H. (1976), The International Operations of National Firms: A Study of Direct Foreign Investment, MIT Press, Cambridge, Massachusetts.

Jacquemin, A., P. Buigues and F. Ilzkocitz (1989), 'Horizontal Mergers and Competition Policy in the European Community', European Economy, No. 40, Commission of the European Communities, Directorate-General for Economic and Financial Affairs (May), pp. 1-57.

Jacquillat, B. and B. Solnik (1978), 'Multinationals are Poor Tools for Diversification', Journal of Portfolio Management (Winter), pp. 8-12.

Jarrell, G.A., J.A. Brickley and J.M. Netter (1988), 'The Market for Corporate Control: The Empirical Evidence Since 1980’, Journal of Economic Perspectives, Vol. 2, No. 2(Winter), pp. 49-68

Jensen, M.C. and R.S. Ruback (1983), ‘The Market for Corporate Control - The Scientific Evidence’ Journal of Financial Economics, Vol. 11, pp.5-50.

Kang, J-K, (1993) 'The International Market for Corporate Control - Mergers and Acquisitions of U.S. Firms by Japanese Firms’, Journal of Financial Economics, Vol. 34, pp. 345-371.

Kaplan, S.N. and M.S. Weisback (1992), 'The Success of Acquisitions: Evidence from Divestitures', Journal of Finance, Vol. 47, No. 1 (March), pp.107-138.

Kennedy, V.A. and R.J. Limmack (1996), 'Takeover Activity, CEO Turnover, and the Market for Corporate Control', Journal of Business Finance \& Accounting, Vol. 23, No. 2 (March), pp. 267-285.

Lessard, D. (1993), 'Comment' to D.L. Swenson, 'Foreign Mergers and Acquisitions in the United States', in K.A. Froot (Ed.), Foreign Direct Investment (University of Chicago Press), pp. 282-283.

Limmack, R.J. (1991), 'Corporate Mergers and Shareholder Wealth Effects: 1977-1986', Accounting and Business Research, Vol. 21, No. 83, pp. 239-251.

London Business School (1985-1991) (Edited by E. Dimson and P.R. Marsh), Risk Measurement Service, Vol. 7-13, Institute of Finance and Accounting.

Markides, C.C. and C.D. Ittner (1994), 'Shareholder Benefits from Corporate International Diversification: Evidence from U.S. International Acquisitions’, Journal of International Business Studies (Second Quarter), pp. 343-366.

Marr, M.W. Jr., S. Mohta And M.F. Spivey (1993), ‘An Analysis of Foreign Takeovers in the United States’, Managerial and Decision Economics, Vol. 14, No. 4 (Jul/Aug), pp. 285-294.

Martin, K.J. (1996), 'The Method of Payment in Corporate Acquisitions, Investment Opportunities, and Managerial Ownership', Journal of Finance, Vol. 51, No. 4 (September), pp. 1227-1246.

Michel, A. and I. Shaked (1986), 'Multinational Corporations vs. Domestic Corporations: Financial Performance and Characteristics’, Journal of International Business Studies, Vol. 17 (Fall), pp. 89100.

Morgan, E.V. and A.D. Morgan (1990), The Stock Market and Mergers in the United Kingdom, The David Hume Institute, Hume Occasional Paper No. 24.

Panel on Takeovers and Mergers, (1990), The City Code on Takeovers and Mergers and The Rules Governing Substantial Acquisition of Shares.

Peterson, D.R. and P.P. Peterson (1991), 'The Medium of Exchange in Mergers and Acquisitions', Journal of Banking and Finance, Vol. 15, pp. 383-405.

Pringle, R. (1991), The Control of Mergers and Takeovers in the EC, The David Hume Institute, Hume Occasional Paper No. 29.

Roll, R. (1986), 'The Hubris Hypothesis of Corporate Takeovers', Journal of Business, Vol. 59, No. 2, Pt. 1, pp. 197-216.

Servaes, H. (1991), ‘Tobin’s Q and the Gains from Takeovers’, Journal of Finance, Vol. 46, No. 1 (March), 
pp. 409-419.

---- and M. Zenner (1990), The Returns to Foreign Acquisitions in the United States, Center for Research in Security Prices, Working Paper No. 302, (University of Chicago).

Shaked, I., A. Michel and D. McClain (1991), 'The Foreign Acquirer Bonanza: Myth or Reality?', Journal of Business Finance \& Accounting, Vol. 18, No. 3 (April), pp. 431-447.

Shapiro, A.C. (1999), Multinational Financial Management, 6th international edition, Prentice Hall.

Solnik, B.H. (1974), 'Why Not Diversify Internationally Rather Than Domestically?', Financial Analysts Journal (July/August), pp. 48-54. Reproduced in Financial Analysts Journal (January/February), 1995, pp. 89-94.

---- (1996), International Investments, 3rd edition, Addision-Wesley.

Strong, N.C. (1992), 'Modelling Abnormal Returns: A Review Article’, Journal of Business Finance \& Accounting, Vol. 19, No. 4 (June), pp. 533-553.

Stulz, R.M., R.A. Walkling and M.H. Song (1990), 'The Distribution of Target Ownership and the Distribution of Gains in Successful Takeovers’, Journal of Finance, Vol. 45, No. 3 (July), pp. 817833.

Sudarsanam, P.S. (1995), The Essence of Mergers and Acquisitions (Prentice Hall).

----, P. Holl and A. Salami (1996), Shareholder Wealth Gains in Mergers: Effect of Synergy and Ownership Structure', Journal of Business Finance \& Accounting, Vol. 23, No. 5\&6, pp. 673-698.

Sudia, J.A. (1992), Valuation Effects of Takeover Regulation on Multinational Bidders, D.B.A. Thesis, (University of Colorado at Boulder).

Swenson, D.L. (1993), 'Foreign Mergers and Acquisitions in the United States', in Froot, K.A. (Ed.), Foreign Direct Investment (University of Chicago Press), pp. 255- 281.

Tessema, A. (1985), Effect of International Mergers and Acquisitions on Shareholder Returns of Participating U.S. Firms, PhD Thesis, (University of Iowa).

Travlos, N. (1987), 'Corporate Takeover Bids, Methods of Payment, and Bidding Firms’ Stock Returns', Journal of Finance, Vol. 42, No. 4 (September), pp. 943-963.

Vasconcellos, G.M., and R.J. Kish (1998), 'Cross-Border Mergers and Acquisitions: The European-US Experience', Journal of Multinational Financial Management, Vol. 8, pp. 431-450.

Wansley, J.W., Lane, W.R. and Yang, H.C. (1983), 'Shareholder Returns to USA Acquired Firms and Domestic Acquisitions’, Journal of Business Finance \& Accounting, Vol. 10, No. 4, pp. 647-656.

---- J.W., Lane, W.R. and Yang, H.C. (1987), 'Gains to Bidder Firms in Cash and Security Transactions’, The Financial Review, Vol. 22, pp. 403-414.

Weiss, N.A. and Hassett, M.J. (1986), Introductory Statistics, Second Edition (Addison-Wesley Company).

White, H. (1980), 'A Heteroskedasticity-Consistent Covariance Matrix Estimator and a Direct Test for Heteroskedasticity’, Econometrica, Vol. 48, No. 4, pp. 817-838. 
Table 1

Target Company Abnormal Returns

\begin{tabular}{|c|c|c|c|c|c|c|}
\hline \multirow[b]{2}{*}{ Model } & \multicolumn{2}{|c|}{$\begin{array}{c}\text { Domestic } \\
\text { Acquisitions }\end{array}$} & \multicolumn{2}{|c|}{$\begin{array}{l}\text { Cross-Border } \\
\text { Acquisitions }\end{array}$} & \multicolumn{2}{|c|}{$\begin{array}{c}\text { Cross-Border } \\
\text { Effect }\end{array}$} \\
\hline & $\mathrm{SD}$ & MM & $\mathrm{SD}$ & MM & $\mathrm{SD}$ & MM \\
\hline Sample & 514 & 389 & 116 & 96 & 630 & 485 \\
\hline Month: & & & & & & \\
\hline-8 & $-0.0167 * * *$ & $-0.0181^{* * *}$ & -0.0133 & $-0.0177^{*}$ & 0.0034 & 0.0004 \\
\hline-7 & $-0.0137 * * *$ & -0.0089 & -0.0120 & -0.0068 & 0.0017 & 0.0021 \\
\hline-6 & $-0.0130 * * *$ & $-0.0099 *$ & 0.0007 & -0.0002 & 0.0137 & 0.0097 \\
\hline-5 & $-0.0100^{*}$ & -0.0035 & -0.0131 & -0.0081 & -0.0031 & -0.0046 \\
\hline-4 & $-0.0143^{* * *}$ & -0.0064 & -0.0165 & -0.0156 & -0.0022 & -0.0092 \\
\hline-3 & $-0.0227 * * *$ & $-0.0184 * * *$ & $-0.0216 * *$ & $-0.0172 *$ & 0.0011 & 0.0012 \\
\hline-2 & -0.0030 & 0.0049 & $0.0289 * *$ & 0.0210 & $0.0319 * *$ & 0.0161 \\
\hline-1 & $0.0262 * * *$ & $0.0378^{* * *}$ & $0.0544 * * *$ & $0.0690 * * *$ & $0.0282^{*}$ & $0.0312 *$ \\
\hline 0 & $0.1876^{* * *}$ & $0.2029 * * *$ & $0.1960 * * *$ & $0.2105^{* * *}$ & 0.0084 & 0.0076 \\
\hline+1 & -0.0043 & -0.0019 & $0.0277 * *$ & 0.0130 & $0.0320 * * *$ & 0.0149 \\
\hline+2 & $-0.0052 *$ & -0.0034 & 0.0092 & 0.0053 & $0.0144^{* *}$ & 0.0087 \\
\hline+3 & -0.0035 & -0.0033 & $-0.0092 * *$ & $-0.0121^{* * *}$ & -0.0058 & -0.0088 \\
\hline+4 & -0.0060 & $-0.0063^{*}$ & -0.0087 & $-0.0121^{* *}$ & -0.0027 & -0.0058 \\
\hline+5 & 0.0004 & 0.0021 & -0.0003 & 0.0014 & -0.0007 & -0.0007 \\
\hline \multicolumn{7}{|c|}{ Cumulative Abnormal Returns: } \\
\hline$-8,-3$ & $-0.0904 * * *$ & $-0.0651 * * *$ & $-0.0757 * * *$ & $-0.0656 * *$ & 0.0147 & -0.0005 \\
\hline$-2,-1$ & $0.0232 * * *$ & $0.0428 * * *$ & $0.0833 * * *$ & $0.0900^{* * *}$ & $0.0601 * *$ & $0.0472 * *$ \\
\hline $0,+1$ & $0.1833^{* * *}$ & $0.2010^{* * *}$ & $0.2238 * * *$ & $0.2235 * * *$ & $0.0405 *$ & 0.0225 \\
\hline$-2,+1$ & $0.2064 * * *$ & $0.2437 * * *$ & $0.3071 * * *$ & $0.3135 * * *$ & $0.1007 * * *$ & $0.0698 * * *$ \\
\hline$+1,+5$ & $-0.0185^{* * *}$ & -0.0127 & 0.0187 & -0.0045 & $0.0372 * *$ & 0.0082 \\
\hline$-8,+5$ & $0.1018^{* * *}$ & $0.1678 * * *$ & $0.2223 * * *$ & $0.2305 * * *$ & $0.1205 * * *$ & 0.0627 \\
\hline
\end{tabular}

Average abnormal returns to shareholders of UK companies which received domestic and cross-border takeover bids, respectively. The cross-border effect refers to the difference in the levels of mean abnormal returns to target companies in cross-border and domestic acquisitions. The abnormal returns are calculated using 5 different test models, although for brevity the results are only reported for the size deciles (SD) and the market model (MM). The results for the other three models are available from the author upon request. The models are as specified in equations 1 and 2 in the text. Time periods refer to months relative to the month of the bid announcement, which is denoted 0 . Not all target companies remained listed during the months following the takeover bids. (For the size deciles model, the sample size for domestic (cross-border) transactions falls to 501 (102) for month $t+1$, while by time period $t+5$, only 98 (24) targets remain listed). Restricting the analysis to companies which remained listed after the bid will bias the sample towards predominately failed bids. Instead, for targets that were delisted, the return on the share has been assumed to be equal to the benchmark (i.e., abnormal return of zero) during the months where data is missing. (The negative post-bid returns are somewhat larger in magnitude if the sample is restricted to companies that remained listed over the whole event period. Indeed, for these - predominately failed - transactions, the cumulative abnormal returns (with the size deciles model) over the period t-8 to $t+5$ are small, at $6.60 \%$ (9.63\%) in domestic (cross-border acquisitions), and are not statistically significant. The impact of bid outcome on the level of abnormal returns is discussed further in the cross-sectional analysis below). The level of statistical significance of the equally weighted abnormal and cumulative abnormal returns, are tested using the cross-sectional t-test (Strong (1992)). The differences in abnormal returns in cross-border and domestic acquisitions is tested using a two-sample difference in means t-test (Weiss and Hassett (1986)). $*, * *$, and $* * *$ indicate statistical significance at $90 \%, 95 \%$ and $99 \%$ level of significance (using two-tailed tests), respectively. 
Table 2

Sample Characteristics

\begin{tabular}{|c|c|c|c|c|}
\hline & & $\begin{array}{r}\text { Total } \\
\text { Sample }\end{array}$ & $\begin{array}{l}\text { Cross- } \\
\text { Border }\end{array}$ & Domestic \\
\hline Sample & & 630 & 116 & 514 \\
\hline \multirow[t]{4}{*}{ Region } & EU & & $31.9 \%$ & \\
\hline & Non-EU European & & $20.7 \%$ & \\
\hline & US & & $19.0 \%$ & \\
\hline & Rest of the World & & $28.5 \%$ & \\
\hline \multirow[t]{3}{*}{ UK Entry } & Prior UK operations & & $40.5 \%$ & \\
\hline & No prior UK operations & & $18.1 \%$ & \\
\hline & Unclassified (insufficient information) & & $41.3 \%$ & \\
\hline \multirow[t]{3}{*}{ EU Entry } & Prior EU operations & & $55.2 \%$ & \\
\hline & No prior EU operations & & $9.5 \%$ & \\
\hline & Unclassified (insufficient information) & & $35.3 \%$ & \\
\hline Exrate & Mean exchange rate value & & 0.0083 & \\
\hline \multirow[t]{5}{*}{ Payment } & Cash only & $18.6 \%$ & $45.7 \%$ & $12.5 \%{ }^{\text {a) } * * *}$ \\
\hline & Cash w/full ln alt & $16.4 \%$ & $42.2 \%$ & $10.5 \%$ \\
\hline & Equity only & $16.0 \%$ & $0.9 \%$ & $19.5 \%$ \\
\hline & Equity w/full cash alt & $21.8 \%$ & $0.9 \%$ & $26.5 \%$ \\
\hline & Other bids & $27.3 \%$ & $10.3 \%$ & $31.1 \%$ \\
\hline Hostile & Hostile bid & $24.0 \%$ & $22.4 \%$ & $24.4 \%{ }^{a)}$ \\
\hline Competitive & Multiple bidders & $6.7 \%$ & $6.0 \%$ & $6.8 \%{ }^{a)}$ \\
\hline Revised & Offer revised & $12.5 \%$ & $12.1 \%$ & $12.7 \%{ }^{a)}$ \\
\hline Outcome & Failed bid & $17.8 \%$ & $15.5 \%$ & $18.3 \%{ }^{a)}$ \\
\hline \multirow[t]{4}{*}{ Industry } & Industrials \& Resources & $36.6 \%$ & $34.8 \%$ & $36.9 \%{ }^{\mathrm{a})} * *$ \\
\hline & Consumer goods & $18.4 \%$ & $20.5 \%$ & $17.9 \%$ \\
\hline & Services & $29.2 \%$ & $20.5 \%$ & $31.0 \%$ \\
\hline & IT \& Financials & $15.9 \%$ & $24.1 \%$ & $14.2 \%$ \\
\hline \multirow[t]{3}{*}{ Related } & Horizontal & $50.5 \%$ & $65.8 \%$ & $46.9 \%^{\text {a) } * *}$ \\
\hline & Vertical & $17.9 \%$ & $13.2 \%$ & $19.1 \%$ \\
\hline & Conglomerate & $31.6 \%$ & $21.1 \%$ & $34.0 \%$ \\
\hline Stake\% & Mean stake & $8.4 \%$ & $15.6 \%$ & $6.7 \%^{\mathrm{b})} * * *$ \\
\hline $\operatorname{Ln} M V$ & Mean pre-bid market value (log) & 3.277 & 3.619 & $3.200^{\mathrm{b})} * *$ \\
\hline
\end{tabular}


EU refers to cross-border bids by companies based in countries which were members of the European Community at the time of the acquisition, Non-EU European to bids by companies based in other European countries, US to bids by US companies, and Rest of the World to acquisitions by companies based outside of Europe and the US. UK entry refers to whether or not the overseas acquiror had UK operations prior to the bid announcement, while EU entry refers to whether the cross-border bidder had operations within the EU (including the UK) prior to the acquisition. Despite the use of numerous data sources, it has not been possible to verify whether the overseas bidder had UK (EU) operations prior to the bid for all transactions. These unclassified bids are treated as residual categories. The method of payment is classified depending on the method of payment offered in the final bid. Loan alt refers to where the offer contained a full loan note alternative. Hostile is a dummy variable taking the value 0 if the initial offer was not rejected by the Board of Directors of the target company and 1 if the bidder's offer was hostile, Competitive is a dummy variable taking the value 0 if only one company bid for the target and 1 if two of more bidders competed for the target, Revised is a dummy variable taking the value 0 if the offer was not revised and 1 if the terms of the offer were revised (terms of the offer improved by increasing the offer price and/or adding more choice with regard to the method of payment), Outcome is a dummy variable taking the value 0 if the bid was successful (in that the bidding company obtained control of the target company) and 1 if the offer failed, Industry refers to the industry classification of the target company, and is split into four broad categories based on London Stock Exchange industry groupings, Related refers to whether the target and bidding companies operated within the same industries, and is subdivided into three mutually exclusive categories: horizontal (where the two companies operated within the same industry and were competitors prior to the acquisition); vertical (where the two companies operated at different levels within the same industry (e.g., the acquisition of a supplier or customer); and conglomerate (where the target and bidding companies operated within separate industries). Stake \% refers to the percentage holding by the bidding company in the target company at the time of the bid announcement, Ln MV is the log of the pre-bid market capitalization of equity of the target company, and Exchange rate refers to the deviation from the average exchange rate over the two year period prior to the month of the bid announcement (values below zero indicating foreign exchange rate being strong (compared to previous exchange rates) relative to Sterling). ***, and $* * *$ indicate statistical significance at $90 \%, 95 \%$ and $99 \%$ level of significance (using twotailed tests), respectively. Tested using a) Chi-squared and b) difference of mean t-test. 
Table 3

Cross-Sectional Analysis of Cross-Border Target Abnormal Returns

\begin{tabular}{|c|c|c|c|}
\hline Event window & Month 0 & Months $0,+1$ & Months $-2,+1$ \\
\hline Constant & 0.1354 & 0.1390 & $0.3567 * *$ \\
\hline Non-EU Europe & -0.0363 & -0.0493 & -0.1168 \\
\hline US & 0.0514 & 0.0327 & -0.0384 \\
\hline Rest of World & 0.0978 & $0.1377^{* *}$ & 0.0325 \\
\hline Prior UK ops. & -0.1137 & -0.0536 & -0.0147 \\
\hline No prior UK ops. & -0.0482 & -0.0148 & -0.0582 \\
\hline Prior EU ops. & $0.1900 *$ & 0.1368 & 0.0599 \\
\hline No prior EU ops. & 0.1292 & 0.0646 & 0.1224 \\
\hline Exchange rate & 0.2139 & 0.1826 & 0.1961 \\
\hline Cash only & 0.0200 & 0.0546 & 0.0581 \\
\hline Cash w/ln alt & 0.0567 & 0.0786 & $0.1472 *$ \\
\hline Hostile & 0.0651 & 0.0525 & 0.0409 \\
\hline Competitive & 0.0899 & 0.1750 & 0.0643 \\
\hline Revised & -0.0648 & -0.0465 & -0.0951 \\
\hline Outcome & -0.0384 & -0.0482 & -0.0358 \\
\hline Consumer goods & -0.0563 & -0.0202 & -0.0415 \\
\hline Services & 0.0390 & 0.0001 & -0.1096 \\
\hline IT \& Financials & -0.0531 & -0.0386 & $-0.1146^{*}$ \\
\hline Vertical & $0.1254 *$ & $0.1177^{*}$ & 0.0710 \\
\hline Conglomerate & -0.0359 & 0.0036 & -0.0120 \\
\hline Stake\% & 0.0007 & 0.0002 & -0.0008 \\
\hline Log MV & -0.0233 & -0.0242 & -0.0254 \\
\hline Observations $^{\mathrm{a}}$ & 110 & 110 & 110 \\
\hline Adjusted $\mathrm{R}^{2}$ & $2.7 \%$ & $0.3 \%$ & $6.1 \%$ \\
\hline$F$-value & 1.14 & 1.02 & 1.34 \\
\hline P-value & 0.322 & 0.454 & 0.176 \\
\hline
\end{tabular}

Table contains regression output from cross-sectional analysis of abnormal and cumulative abnormal returns to target company shareholders in cross-border acquisitions into the UK. The analysis is undertaken using OLS regressions, controlling for heteroskedasticity (White (1980)). Analysis has also been undertaken using robust rank regressions. Coefficients reported in italics indicate that the OLS and rank regressions provide conflicting results as to the sign or whether or not the coefficient is statistically significant. Variables as defined in Table 2. $*$, **, and $* * *$ indicate statistical significance at $90 \%, 95 \%$ and $99 \%$ level of significance (using two-tailed tests), respectively. a) Some of the cross-sectional variables were not available for all companies, thus reducing sample sizes. (Restricting the analysis to targets which remained listed during month $\mathrm{t}+1$ reduce the sample size to 96 . For the $t$ to $t+1$ event window, the changes in the size of the non-significant coefficients are generally trivial, and there is no change in the sign of the significant coefficients. However, the constant and coefficients on 'non-EU European' and ' $\log \mathrm{MV}$ ' gain significance, while the coefficient on 'rest of the world' is no longer significant. The adjusted $\mathrm{R}^{2}$ increase to $7.8 \%$, although the regression overall remain not significant. For the $\mathrm{t}-2$ to $\mathrm{t}+1$ event window, the coefficients for the four dummy variables for UK and EU operations all switch sign under OLS regression (but remain insignificant), while the coefficients retain the reported signs under robust rank regressions. This suggests that large observations have a bigger impact on the OLS regressions for the restricted than for the full sample, due to the smaller sample size. While the signs remain robust, the coefficients for 'cash w/ln alt' and 'IT \& financials' lose significance for the restricted sample, and the adjusted $\mathrm{R}^{2}$ drops to $0.0 \%$ ). 
Table 4

Cross-Sectional Analysis of Domestic Targets and Total Sample Abnormal Returns

\begin{tabular}{lc|c|c}
\hline Event window & Month 0 & Months 0, +1 & Months $-2,+1$ \\
Constant & $0.2144^{* * *}$ & $0.2021^{* * *}$ & $0.2589^{* * *}$ \\
Cross-Border & -0.0256 & -0.0021 & 0.0326 \\
Cash only & -0.0025 & 0.0012 & -0.0205 \\
Cash w/ln alt & 0.0280 & 0.0442 & $0.1116^{* * *}$ \\
Equity only & $-0.0875^{* * *}$ & $-0.0830^{* * *}$ & $-0.1250^{* * *}$ \\
Equity w/cash alt & -0.0249 & -0.0351 & -0.0382 \\
Hostile & 0.0165 & 0.0397 & 0.0254 \\
Competitive & 0.0212 & $0.0881^{* *}$ & $0.0785^{*}$ \\
Revised & 0.0269 & 0.0282 & 0.0442 \\
Outcome & -0.0294 & $-0.0755^{* * *}$ & $-0.0748^{* *}$ \\
Consumer goods & 0.0133 & 0.0333 & 0.0241 \\
Services & -0.0260 & -0.0188 & -0.0284 \\
IT \& Financials & -0.0392 & -0.0248 & -0.0496 \\
Vertical & 0.0029 & -0.0114 & -0.0043 \\
Conglomerate & -0.0128 & -0.0085 & -0.0080 \\
Stake\% & -0.0005 & -0.0006 & -0.0005 \\
Log MV & 0.0023 & 0.0023 & -0.0038 \\
Observations & 595 & 595 & 595 \\
Adjusted R ${ }^{\mathrm{a}}$ & $2.2 \%$ & $3.8 \%$ & $8.2 \%$ \\
F-value & $1.85^{* *}$ & $2.48^{* * *}$ & $4.32^{* * *}$ \\
\hline
\end{tabular}

Table contains regression output from cross-sectional analysis of abnormal and cumulative abnormal returns to target company shareholders in domestic and cross-border acquisitions into the UK. The analysis is undertaken using OLS regressions, controlling for heteroskedasticity (White (1980)). Analysis has also been undertaken using robust rank regressions. All coefficients have the same sign and level of significance under OLS and robust rank regressions. Variables as defined in Table 2. Cross-Border is a dummy variable taking the value 1 in cross-border acquisitions. *, **, and *** indicate statistical significance at $90 \%, 95 \%$ and $99 \%$ level of significance (using twotailed tests), respectively. a) Some of the cross-sectional variables were not available for all companies, thus reducing sample sizes. (Restricting the analysis to targets which remained listed during month $\mathrm{t}+1$ reduce the sample to 569 observations. For the t to $\mathrm{t}+1$ event window, the coefficient for the 'cross-border effect' switch sign from an insignificant $-0.21 \%$ to a still insignificant $+1.12 \%$. None of the other coefficients alter noticeably, and there are no changes to the significance levels of the coefficients. The overall explanatory power of the model improves marginally, with an adjusted $\mathrm{R}^{2}$ of $4.9 \%$. For the $\mathrm{t}-2$ to $\mathrm{t}+1$ window, all coefficients maintain their sign and significance levels, except for 'conglomerates', which switch sign from $-0.80 \%$ to $+0.32 \%$, although neither coefficient is significant. The adjusted $\mathrm{R}^{2}$ falls marginally, to $7.5 \%$ ). 


\section{Notes}

1 If markets for corporate control are segmented across national boundaries, domestic and cross-border acquisitions may produce different levels of abnormal returns (Fatemi and Furtado, 1988). The rules and regulations governing mergers and acquisitions, or the efficiency of the market for corporate control, may also have an impact on the level of abnormal returns (Conn and Connell, 1990). However, although these factors may result in different levels of abnormal returns to target shareholders in different countries, and to different levels of acquiror returns in domestic and crossborder acquisitions, the segmented or inefficient takeover markets hypotheses are unlikely to account for differential target wealth effects in domestic and cross-border acquisitions within a country.

A further consideration relates to the scope for cost savings post acquisition. Jacquemin et al. (1989) find cross-border acquisitions within the EU to reveal little evidence to suggest that these transactions result in greater efficiencies or that economies of scale or monopoly powers are exploited. Indeed, economies of scale may be easier to achieve in domestic than in cross-border acquisitions. If acquiring companies share cost savings with target shareholders, this would suggest that target shareholders may gain more in domestic than in cross-border acquisitions. The effect of differential cost savings following domestic and cross-border acquisitions is not analysed in this study.

There is also a possibility that bidding companies based in some countries will be subject to more favorable tax treatment or accounting regulation than companies from other countries. This may affect their ability or willingness to pay high takeover premia (Choi and Lee, 1991). Eighteen overseas countries are represented in the cross-border acquisitions into the UK covered in this study. An analysis of the different accounting regulations or tax treatments in these countries is beyond the scope of this paper.

Hymer (1976) argues that foreign investors may be at a cost disadvantage relative to domestic ones, with e.g., cultural differences and geographical distance adding to the cost and complexity of the transaction (Dewenter (1995)). Regulatory and economic barriers may also reduce the probability of success of a cross-border bid. Consequently, the merger premium the bidder is willing to pay may be lower in cross-border than in domestic transactions. (I am grateful to the referee for bringing these arguments to my attention). While such costs may deter overseas companies from attempting to acquire UK companies (reducing the number of cross-border bids we observe), they are unlikely to result in a negative target company cross-border effect. If takeover markets are competitive, foreign companies deciding to acquire UK firms are likely to have to pay at least as high premia as domestic bidders for their targets, despite the higher costs associated with cross-border acquisitions. We may therefore expect to find no difference in the abnormal returns in domestic and cross-border acquisitions, although we are unlikely to observe a negative target company cross-border effect. However, to allow for the theoretical possibility of a negative effect, we apply two-tailed tests of statistical significance in the analysis of target company cross-border effects.

These sample sizes refer to those for the size deciles model. Due to their generally more stringent data requirements, the sample sizes for the other test models are generally somewhat lower. During the six year period of analysis, 756 domestic and 208 cross-border takeover bids were announced. However, as the analysis is based on ordinary shares, 3 domestic bids for preference shares are excluded from the analysis. In addition, partial takeover bids (5 cross-border and 8 domestic) are excluded, as these bids require special dispensation from the Takeover Code (The Panel on Takeovers and Mergers (1990)); as is common in event studies (e.g., Dimson and Fraletti (1986), bids for investment trusts ( 9 cross-border and 43 domestic) are excluded due to different valuation issues relating to such companies; bids for water companies (13 cross-border and 6 domestic) are excluded as such bids are strictly regulated through the Water Act 1989 (DTI (1991); bids where two or more companies jointly bid for the target (2 cross-border and 9 domestic) are excluded, as are ( 1 cross-border and 3 domestic) follow-on bids by the same bidder for the same target within a twelve month period. In order to avoid double-counting, target companies are only included once in competitive bidding contests, with the bid date and characteristics being based on the first bid/bidder. Bids by second and subsequent bidders have been excluded (21 cross-border and 41 domestic). Finally, bids where the Acquisitions Monthly listing (4 cross-border and 15 domestic) is incomplete is excluded from the analysis. Following this screening process, 153 cross-border and 628 domestic bids remain. Lack of return data further reduces the sample to 122 cross-border and 527 domestic takeover bids. The abnormal returns (CAR from $t-2$ to $t+1$ ) are more than 3 standard deviations away from the mean for 4 cross-border and 10 domestic bids. These outliers are removed. Market capitalization data are missing for 2 cross-border and 3 domestic targets, resulting in a final sample of 116 cross-border and 514 domestic acquisitions for the size deciles model. 
3 Market values are obtained from the quarterly issue published 6 to 9 month prior to the bid announcement, in order to ensure that the values are not influenced by rumours regarding the forthcoming bid announcement.

The nationalities of the bidding companies in the 116 cross-border acquisitions are: Australia (11), Belgium (1), Canada (4), Eire (3), Finland (3), France (15), Germany (8), Hong Kong (1), Japan (6), Liechtenstein (3), Luxembourg (1), Netherlands (6), New Zealand (8), South Africa (1), Saudi Arabia (1), Sweden (13), Switzerland (9), and US (22).

The other test models are specified as follows:

IM: $\quad \mathrm{R}_{\mathrm{it}}=\mathrm{R}_{\mathrm{mt}}+\mu_{\mathrm{it}}$

CAPM: $R_{i t}=R_{f t}+\beta_{i}\left(R_{m t}-R_{f t}\right)+\mu_{i}$

HGSC: $\quad \mathrm{R}_{\mathrm{it}}=\mathrm{R}_{\mathrm{ft}}+\beta_{1 \mathrm{i}}\left(\mathrm{R}_{\mathrm{mt}}-\mathrm{R}_{\mathrm{ft}}\right)+\beta_{2 \mathrm{i}}\left(\mathrm{R}_{\mathrm{HGt}}-\mathrm{R}_{\mathrm{mt}}\right)+\mu_{\mathrm{it}}$

where $R_{f}$ refers to the risk-free interest rate, $R_{m}$ the return on the Financial Times Actuaries index for the UK market, $\alpha_{i}$ and $\beta_{i}$ are regression coefficients, and $R_{H G}$ the return on the Hoare Govett small companies index. The HGSC model is discussed further in Gregory (1997). Results based on these test models are available from the author upon request.

The level of statistical significance is also tested using the Wilcoxon signed-rank nonparametric test of the median. The level of statistical significance using this test (not reported) is overall very similar to those using the t-test, and provide consistent conclusions to those drawn based on the parametric statistics. All significance levels are based on two-tailed tests.

A correlation matrix for all variables was produced for the total sample, as well as for the samples of domestic and cross-border acquisitions separately. For brevity, we do not report the full correlation matrix, but it is available upon request. As explained further in the analysis, a few independent variables are significantly correlated. In these circumstances, various tests have been undertaken to test the robustness of the results.

Factors affecting the decision as to what form of payment to offer include not only tax considerations and information effects. As discussed in Martin (1996), other aspects affecting the payment decision include managerial ownership and control issues, pre-bid share performance, cash balances, the importance of institutional shareholders and block holders, and the presence of growth opportunities.

Another variable, which has in the literature been found to be of some importance, is the relative size of the target and bidding companies. For the UK, Sudarsanam et al. (1996) find target company shareholders to gain more when their company is small relative to the size of the bidder. However, in this study, data on the market value of the bidding company is missing for 256 acquisitions. The variable was included in additional regressions (not reported), but was not found to be significant for any of the event windows with any of the samples.

For prior UK (EU) operations, data was missing for $41.4 \%$ (35.3\%) of the transactions. This is similar to Fatemi and Furtado (1988), who in their analysis of cross-border acquisitions into the US found $79.5 \%$ to have prior US operations, $1.7 \%$ not to have prior operations, and $18.8 \%$ not known. The results are similar and the conclusions robust to whether 'no information' is treated as a third category or (as do Fatemi and Furtado) combined with the 'no prior UK (EU) operations' categories.

There is a potential problem of colinearity between the 'prior UK operations' and 'prior EU operations' variables, due to a correlation coefficient of 0.744 between the variables. In regressions excluding controls for prior EU operations, all of the coefficients for 'no prior UK operations' remain insignificant, as do the coefficients for 'prior UK operations'. The finding of no support for the UK market access hypothesis is thus robust. Similarly, excluding controls for prior UK operations, all of the coefficients for 'no prior EU operations' remain insignificant, while the coefficients for 'prior EU operations' are significantly positive for the short and medium windows. We therefore continue to reject the EU market access hypothesis.

There are only one each of 'equity only' and 'equity with full cash alternative' bids present in the cross-border sample. Due to the small samples, these observations are included in the residual payment category captured by the intercept. However, additional analysis (not reported) with these two variables included in the analysis, indicate that the abnormal return in the one 'equity with full cash alternative' bid is significantly lower than for other cross-border bids (for the two short event windows), although the coefficient for 'equity only' is not significant. 
The correlation coefficients are in particular high between 'hostile' and 'revision' (0.450), 'hostile' and 'outcome' (0.507), and 'competitive' and 'outcome' $(0.442)$, while the correlation coefficients for the other three pairs of variables are all below 0.210 . 